\title{
The Trauma of Female Gender with Special reference to Henry James Novel "The Portrait of a Lady"
}

\author{
Dr. Farhana Tabassum \\ Asstt. Prof., Jeddah University, Saudi Arabia
}

\begin{abstract}
:
Females have been a silent feature for the majority of human history, their thoughts, and feelings are not considered being of theleast importance. Henry James has embellished the social responsibilities of marriage vows very critical for women. James was a critic of middle class conjugal life and magnifies the trauma of middle class women. Philosophically the central theme of the topic explains the word Trauma which literally means the ferociousness of the male gender on the females in the form of suppression. Under the difficult circumstances, women were submissive but through her works, they fought the social forces and attempted to create their own identity. The novel 'The Portrait of a lady'depicts a tradition from innocence of the Isabel Archer who claimed to be fond of her freedom surrounded with a number of challenging women. The portrait of a lady is not the end of Isabel story but story of women changing place in society because it was even forbidden for the women to break the norms of patriarchal conventions. Henry James choice is based on interest and revolutionary themes regarding women in The Portrait of a Lady which challenges the society and its rules of the Nineteenth century regarding women position, their behavior expectations and their challenges against the traumatic conditions of the society.
\end{abstract}

Keywords :Traumatic; Henry James.

Reference to this paper should be made as follows:

\section{Dr. Farhana Tabassum,}

The Trauma of Female Gender with Special reference to Henry James Novel "The Portrait of

$$
\text { a Lady", }
$$

Notions 2018, Vol. IX, No.2, pp. 18-22, Article No. 4

Online available at : http://anubooks.com/ ?page_id=34 
The most prominent American Novelist of the nineteenth century who depicted women suffering and issues in both American and European societies is Henry James. The exemplary works of Henry James regarding genders and women challenges of the patriarchal convections are "The Portrait of a Lady" and Wings of the Dove".

Philosophically the central theme of the topic explains the word Trauma which literally means the cruelness of the male gender on the Females in the form of suppression .Men and Women in America and Europe a accommodated the idea of separate by society where women were not considered at par to men therefore the feminine gender didn't have the same rights and opportunities at par to men. The women had passion for learning and gaining Knowledge yet educated women were often ignored by the society. This claim was supported by Victorian physician and anthropologist with the argument that women's inferiority could be seen by analyzing the brain. According to them women had smaller brains which were not so efficient as man's brain.

"To live only to suffer-only to feel the injury of life repeated and enlarged

-it seemed to her she was too valuable, too capable, for that.

Then she wondered if it were vain and stupid to think so well of herself.

When had it even been a guarantee to be valuable?

Wasn't all history full of the destruction of precious things?

Wasn't it much more probable that if one were fine one would suffer?" 1

\section{Discussion - The Portrait of a Lady}

The Portrait of a lady is an American trait of initiation story of a young selfdetermining American girl who was facing Victorian norms in Henry James Fiction. The novel depicts a tradition from innocence of the Isabel Archer who claimed she is fond of her freedom surrounded with a number of challenging women. The portrait of a lady portrays the powerful women standing against thepatriarchal gender imposed by the Victoriansociety. It is composed of two doctrines 'separate spheres' and the 'angel in the house'whereas the social life, the public spheres travel and independency prolonged to the masculine gender. Though women had the desire and eagerness of becoming part of these males spheres. The novel present the women throughout various types of female social existence of nineteenth century convections, though the women still feels that travel is a means which provides some idea of freedom and furnished them with power.On one side, there are, immovable women, controlled to the narrow limits of the domestic compass as Pansy; On the other side, there are 
The Trauma of Female Gender with Special reference to Henry James Novel "The Portrait of a Lady" Dr. Farhana Tabassum

the „movable women as Isabel Archer, Henrietta Stackpole, Lydia Touchett and Madame Merle, who seem to travel even more than the male characters.

James Clifford argues that during the Victorian Age :

"it was not usual to see the bourgeois and white women

travelling and if they did so they were forced to conform,

masquerade, or rebel discreetly within a set of normatively

male definitions and experiences" 2

An Italian scholar Marcella Romeo agrees that travelling alone in a exterior

place, for a woman was considered as a worsening act, hence it was another traumatic state of mind for women to move from one place to another and it was difficult to accept for the patriarchal society to see a woman travelling alone. In Henry James Portrait of a Lady, most of the female characters are American expatriates, they have the eagerness of travelling to many places despite the patriarchal rules and the traditional modes of social existence imposed on women during the nineteenth century.

The portrait of a lady is a form of search, a woman for a vocation who surrenders herself for marriage for fear. Isabel is squad woman, belong to new breed but who hasn't understand a sexual freedom and thus passes a painful marriage . It is a sexual affair that she thinks to her own shock. She was not the daughter of Puritans who believes in chastity and decency.

Henry James has dramatized the social responsibilities of marriage vows which are very crucial for women. James was a critic of middle class marital life and magnifies the trauma of middle class women. James never afford to allow the experimental female walk away from domestically such Isabel Archer was allowed to choose her fate but she has no option except marriage otherwise the society will discard her as an indecent.

Henry James has already abolished the traditional style of matrimonial novel writing which originally ends with the engagement or the marriage of the heroine, Borchers names

The Portrait of a Lady the predecessor of the modern novel about marriage matters 3 (116).

In The Portrait of a Lady, there is hardly a chance for love between men and women, neither in legitimate relationships, or in illegitimate relationships, nor in alternative relationships.

"Isabel admires herself as an adventurer who has belief in free will but she was crying and shouting "I want to live" rather than "I am living. 
"Isabel's dashing, ne'er-do-well father only

wanted to protect his little girls from the world - and,

as a result, Isabel feels as though she hasn't really seen life at all" 4 .

The portrait of a lady is not the end of Isabel story but story of women changing place in society because it was even forbidden for the professional women to travel alone. It was necessary either a family member or servant should accompany a travelling woman for e.g. when Castell wish to visit her publisher at London in 1894 in order to meet literary people, she took another woman with her to travel as chaperone since her husband was busy at Manchester. In the portrait of lady Henry James clarifies that most of the female characters are American Expatriates who were eager to travel a number of places despite of male-controlled rules and traditional system of social life imposed on women in $19^{\text {th }}$ century.

Isabel was forced to undergo the subordinationship under a male dominance Isabel Archer has played three females characters or we can say three roles, first of all as an unmarried lady in Guardian court, secondly comes to live as a wife in Rome and finally as a mother. In this way none in the novel is limited in their social female position as unmarried, married and mothers. Obviously these traditional modes of female separately competes and perpetuates the most common task of the female gender which object physically and economically dependence on males.

James also overruled a supremacy of authoritative women upon a weak women in The portrait of a lady. In further explanation Pansy's character is remarkable effected by the convention of Victorian age, she was kept as a doll in Serena's hands to search a proper husband for her. She was not allowed to educate or cultivate her experience of life.

\section{Conclusion}

Thus women confines with a narrow outlook with traditional social existence of mothers, wives and sisters . On the other hand men were reserved for the public and social work associated with mobility and freedom. Therefore travelling was men property and forbidden for women with illegal prostitution. James always handles the gender roles and present roles, the challenging female characters like Isabel ,Mrs. Touchette and Madam Merle even then women seen as objects like Pansy. In This respect Henry treatment of women makes him a feminist writer since he represents women state and signifies the restrictive bond on them by masculine conventions.

Henry James has put forward a consistent and coherent and even very modern idea of identity through endeavor to represent the consciousness of the novels, 
The Trauma of Female Gender with Special reference to Henry James Novel "The Portrait of a Lady" Dr. Farhana Tabassum

female characters after a deep and thorough investigation it may be concluded that Henry James choice is based on interest and revolutionary themes regarding women in The Portrait of a Lady which challenges the society and its rules of the Nineteenth century regarding women position,their behavior expectations and their challenges against the traumatic conditions of the society.

"You wanted to look at life for yourself - but you were not allowed; you were punished for your wish. You were ground in the very mill of the conventional." 5

\section{Notes}

1-Henry James, The Portrait of a Lady

2-qtd in Kemaloðlu 112

3-Relationships in Henry James “Portrait of a Lady"2007 pp. 116

4-Henry James, The Portrait of a Lady

5- Henry James, The Portrait of a Lady

\section{References}

James, Henry. The portrait of a Lady. Beirut: Dar Al-Bihar, 2005.

The Variety of Feminisms and their Contribution to Gender Equality. Oldenburg: Bibliotheks- und Informationssystem der Univ, 1997. Pdf Matthews, Glenna.

A literature of their Own, British Women Novelist from Bronte to Lessing. Princeton, N.J: Princeton University Press.1977.

A literature of their Own, British Women Novelist from Bronte to Lessing. Princeton, N.J: Princeton University Press.1977.

"Travelling and Gender: The portrait of a Lady". Journal of Social and Human Scientific Researchers. Turkey: Muðla University Social Sciences Institute Magazine (ÝLKE), 2010.

"Marriage and the New Woman in The Portrait of a Lady". American Literature. vol.3, no.47, pp 377-395.

Female Mobile Identities and Southern Italy in the 19th Century Non-feminist Periodical Press". Journal of Literature and Art Studies. vol. 6, no. 11, November 2016, pp. 1263-1277. 